\title{
Some Works on Comfort Girls-Women
}

Henson, Maria Rosa. Comfort Woman: A Filipina's Story of Prostitution and Slavery under the Japanese Military. 2nd ed. Lanham, MD: Rowman \& Littlefield, 2017.

Hicks, George. The Comfort Women: Japan's Brutal Regime of Enforced Prostitution in the Second World War. New York: W. W. Norton \& Co., 1997.

Howard, Keith, ed. True Stories of the Korean Comfort Women. Translated by Young Joo Lee. New York and London: Cassell, 1995.

Kim-Gibson, Dai Sil. Silence Broken: Korean Comfort Women. Parkersburg, IA: Mid-Prairie Books, 1999.

Min, Pyong Gap, Thomas Chung, and Sejung Sage Yim, eds. Japanese Military Sexual Slavery: The Transnational Redress Movement for the Victims (Genocide and Mass Violence in the Age of the Extremes 2). Berlin: Walter de Gruyter, 2019.

Pilzer, Joshua D. Hearts of Pine: Songs in the Lives of Three Korean Survivors of the Japanese “Comfort Women.” New York: Oxford University Press, 2012.

Qiu, Peipei with Su Zhiliang and Chen Lifei. Chinese Comfort Women: Testimonies from Imperial Japan's Sex Slaves. New York: Oxford University Press, 2013.

Ruff-O'Herne, Jan. Fifty Years of Silence: The Extraordinary Memoir of a War Rape Survivor. Pune, India: Mehta Publishing House, 2008.

Schellstede, Sangmie Choi, ed. Comfort Women Speak: Testimony by Sex Slaves of the Japanese Military. New York: Holmes \& Meier, 2000.

Soh, C. Sarah. The Comfort Women: Sexual Violence and Postcolonial Memory in Korea and Japan. Chicago and London: University of Chicago Press, 2008.

Son, Elizabeth W. Embodied Reckonings: "Comfort Women," Performance, and Transpacific Redress. Ann Arbor: University of Michigan Press, 2018.

Stetz, Margaret and Boonie B. C. Oh, eds. Legacies of the Comfort Women of World War II. New York: M. E. Sharpe, 2001.

Tanaka, Yuki. Japan's Comfort Women: Sexual Slavery and Prostitution during World War II and the US Occupation. London and New York: Routledge, 2002.

Ueno, Chizuko. Nationalism and Gender. Translated by Beverley Yamamoto. Melbourne: Trans Pacific Press, 2004

Yoon, Mee-Hyang. 25 Years of Wednesdays: The Story of the "Comfort Women" and the Wednesday Demonstrations. Translated by Koeun Lee. Seoul: The Korean Council for Justice and Remembrance for the Issues of Military Sexual Slavery by Japan, 2019.

Yoshimi, Yoshiaki. Comfort Women: Sexual Slavery in the Japanese Military during World War II. Translated by Suzanne O’Brien. New York: Columbia University, 1995.

Ә Open Access. () 2020 Angella Son, published by De Gruyter. (cc) BY-NC-ND This work is licensed under a Creative Commons Attribution-NonCommercial-NoDerivatives 4.0 International License.

https://doi.org/10.1515/9783110670523-017 
